\title{
Sacral Neuromodulation: A Worldwide Survey Conducted Among Surgeons
}

\author{
A Ghazi ${ }^{{ }^{*}}$, A Alabbad ${ }^{1}$ and M. Hassouna ${ }^{2}$ \\ ${ }^{1}$ Members of the Neurourology Promotion Committee of the ICS \\ ${ }^{2}$ Toronto Western Hospital, University of Toronto, Toronto, Canada.
}

Received: July 10, 2017; Accepted: August 9, 2017; Published: August 29, 2017

*Corresponding author : Abdullah Ghazi, Members of the Neurourology Promotion Committee of the ICS. E-mail: aaq997@yahoo.com

\begin{abstract}
Aim and Objectives: The purpose of this study was to conduct a pre-guideline survey of surgeons involved in InterStim ${ }^{\circledR}$ therapy for Sacral Neuromodulation (SNM). The data gathered from the survey may serve as an important baseline in the development of a guideline for SNM implantation.
\end{abstract}

Methods: Surgeons implanting SNM were surveyed using an Internet-based program between November and April of 2016. The survey was posted on the included a questionnaire.

We used a questionnaire that covered various clinical aspects involved in the delivery of SNM. The questionnaire was posted on-line via Survey Monkey for a period of 5 months. The entire process was under the auspices of the Neurourology Promotion Committee of the International Continence Society (ICS).

Results: 49 surgeons who are involved in SNM implant filled out the survey. We searched the literature about the best practices in those areas of interest in the delivery of SNM. We found a discrepancy in the surgical approach for SNM. Based on the results of the survey, we found discrepancies in the following areas: preoperative evaluation: voiding diary, X-ray of sacrum, uroflowmetry, urodynamic study and cystoscopic evaluation. Screening: percutaneous nerve evaluation versus stage implant. Surgical technique: anesthesia used position of electrode in sacral foramina, type of stylet and number of optimum electrodes used for stimulation. Postoperative: duration of antibiotic and number of programs given to the patient. Those differences were not based on any scientific basis in the literature rather on individual practice.

Conclusion: In the current manuscript, we described the different nuances in the standard of practice for surgeons involved in the delivery of SNM therapy.

As evidenced by the discrepancy in the responses, we think that this is the initial step in the preparation for a guideline describing the best policy to deliver the SNM.

Key words: Sacral Neuromodulation

\section{Introduction}

Sacral Neuromodulation (SNM) with the InterStim ${ }^{\circledR}$ system therapy (Medtronic Inc., Minneapolis, Minnesota USA) has been a US Food and Drug Administration (FDA)-approved medical device for urgency-frequency syndrome since 1997, and for idiopathic non-obstructive urinary retention since 1999 [1]. Additionally, it was approved for voiding dysfunction by Health Canada in February 2002 (Class IV, License No. 14962) [1,2].

Prospective, retrospective, and post-approval studies demonstrate that Sacral Neuromodulation for Bladder Control (delivered by the InterStim ${ }^{\circledR}$ System) is safe and effective $[3,4]$. It has superior efficacy and greater quality of life compared to medication [3]. It has 12-months clinical success and 5-year study shows sustained efficacy [4].

The mechanism of action for SNM is not fully understood. It is likely work by alters of sacral afferent inflow on storage and emptying reflexes at the spinal level [5]. Also, it appears to restoring brainstem auto-regulation [6]. However, there have been several innovations in its surgical techniques methodology since the initial FDA approval in 1997 [1]. At the time of the initial FDA approval, there were very few surgeons who possessed versatile surgical techniques in this field in North America and Europe. Due to high success rate (60\%-70\%) from earlier randomized studies followed by studies with confirmatory results, these surgeons started proctoring any interested physician or surgeon in delivering the therapy for the subsequent 3-4 years that followed the initial FDA approval [7-10]. Every proctor was teaching the technique to the best of their knowledge to their surgeon colleagues. However to date, there has been no standard guidelines to help the surgeons to consistently maximize the benefit for the patients who require implantations.

Therefore, it is expected that there are subtle differences among all implanters when delivering the therapy.

In the current work, we polled surgeons involved in SNM therapy with questions describing their methodology for the delivery of the therapy. We present the results of the poll in an attempt to propose a guideline that describes the minimal requirements for proper implantation of SNM.

\section{Materials and Methods}

We designed an electronic survey on Survey Monkey to 
include 36 questions for a period of 5 months (November 2015 to April 2016). The survey was designed to cover all major aspects of this type of surgery from a surgeon's point of view. Since the implantation can be done by experts with different specialties, e.g., urologist, gynecologist and colorectal surgeon, the survey was put available by the ICS instead of highly specialized organizations to minimize bias. The first part of the survey was general questions about the responders' background information (Q1-Q7). Q8 was designed to discuss about the indications for surgeons to consider Interstim implantation (options based upon indications approved by FDA and literature review) [1113]. Pre-op evaluation was covered by Q9-Q15 and Q15-18 discussed about screening test. The employments of prophylactic antibiotics were mentioned in Q23 whilst the detailed surgical techniques were polled in Q24-31. The survey was then finished with the post-op care questions and complications. The questions are listed in Appendix 1. All the answers to those questions are tabulated in the diagrams presented in the Results section. The survey link was send to the surgeons by the International Continence Society (ICS).

\begin{tabular}{|c|c|}
\hline \multicolumn{2}{|l|}{ Appendix 1} \\
\hline Question & Options \\
\hline \multicolumn{2}{|l|}{ Initials } \\
\hline \multicolumn{2}{|l|}{ Center } \\
\hline \multicolumn{2}{|l|}{ City } \\
\hline \multicolumn{2}{|l|}{ Country } \\
\hline $\begin{array}{l}\text { Period of experience of } \\
\text { implanter: }\end{array}$ & $\begin{array}{ll}\cdot & <5 \\
\text { - } & 5-10 \\
\text { - } & 10-20 \\
\text { - } & >20\end{array}$ \\
\hline $\begin{array}{l}\text { Who cover the device cost? } \\
\text { (you can choose more than } \\
\text { one) }\end{array}$ & $\begin{array}{ll}\text { - } & \text { Government } \\
\text { - } & \text { Insurance companies } \\
\text { - } & \text { The patient }\end{array}$ \\
\hline $\begin{array}{lrr}\text { Number of } & \text { sacral } \\
\text { neuromodulation } & (\mathrm{SNM}) \\
\text { (internal pulse } & \text { generator) } \\
\text { annually? } & & \end{array}$ & $\begin{array}{ll}\text { - } & 1-10 \\
\text { - } & 11-20 \\
\text { - } & 21-50 \\
\text { - } & 51-100 \\
\text { - } & >100\end{array}$ \\
\hline $\begin{array}{l}\text { Indication of SNM? (you can } \\
\text { choose more than one) }\end{array}$ & $\begin{array}{ll}\text { - } & \text { Refractory over active bladder } \\
\text { - } & \text { Chronic urinary retention } \\
\text { - } & \text { Chronic pelvic pain syndrome } \\
\text { - } & \text { Fecal incontinence } \\
\text { - } & \text { Other }\end{array}$ \\
\hline $\begin{array}{l}\text { I am using voiding diary from } \\
\text { Medtronic for preoperatively } \\
\text { evaluation? }\end{array}$ & $\begin{array}{ll}\text { - } & \text { Yes } \\
\text { - } & \text { No, using other diary }\end{array}$ \\
\hline
\end{tabular}

\begin{tabular}{|c|c|}
\hline $\begin{array}{l}\text { I am doing a routine sacral } \\
\text { x-ray preoperatively? }\end{array}$ & $\begin{array}{ll}\text { - } & \text { Yes } \\
\text { - } & \text { No, using other image }\end{array}$ \\
\hline $\begin{array}{l}\text { I am doing routinely simple } \\
\text { uroflowmetry and post void } \\
\text { residual? }\end{array}$ & $\begin{array}{ll}\text { - } & \text { Yes } \\
\text { - } & \text { No }\end{array}$ \\
\hline $\begin{array}{l}\text { I am doing routinely } \\
\text { Urodynamic study? }\end{array}$ & $\begin{array}{ll}\text { - } & \text { Yes } \\
\text { - } & \text { No }\end{array}$ \\
\hline $\begin{array}{l}\text { I am doing Cystoscopy } \\
\text { routinely }\end{array}$ & $\begin{array}{ll}\text { - } & \text { Yes } \\
\text { - } & \text { No }\end{array}$ \\
\hline $\begin{array}{l}\text { Factors to choose the battery } \\
\text { size (you can choose more } \\
\text { than one) }\end{array}$ & $\begin{array}{ll}\text { - } & \text { Surgeon preference } \\
\text { - } & \text { Patient choose } \\
\text { - } & \text { Cost } \\
\text { - } & \text { Indication } \\
\text { - } & \text { Age } \\
\text { - } & \text { Other }\end{array}$ \\
\hline $\begin{array}{l}\text { For screening, due do (as } \\
\text { beginning) }\end{array}$ & $\begin{array}{ll}\text { - } & \text { PNE } \\
\text { - } & \text { Stage } \\
\text { - } & \text { Both, depend on indication }\end{array}$ \\
\hline $\begin{array}{l}\text { What are you doing for PNE/ } \\
\text { stage I }\end{array}$ & $\begin{array}{ll}\text { - } & \text { Unilateral stimulation } \\
\text { - } & \text { Bilateral stimulation }\end{array}$ \\
\hline Fluoroscopy used routinely: & $\begin{array}{ll}- & \text { Yes } \\
\text { - } & \text { No }\end{array}$ \\
\hline $\begin{array}{l}\text { I am doing a routine sacral } \\
\mathrm{x} \text {-ray to evaluate the electrode } \\
\text { position at follow up after } \\
\text { PNE? }\end{array}$ & $\begin{array}{ll}- & \text { Yes } \\
- & \text { No } \\
& \\
\end{array}$ \\
\hline $\begin{array}{l}\text { Indication of good position: } \\
\text { (you can choose more than } \\
\text { one) }\end{array}$ & $\begin{array}{ll}\text { - } & \text { Sensory } \\
\text { - } & \text { Motor (lavetor ani) } \\
\text { - } & \text { Foot/toe movement } \\
\text { - } & \text { Fluoroscopy } \\
\text { - } & \text { Other }\end{array}$ \\
\hline $\begin{array}{l}\text { Anesthesia used (you can } \\
\text { choose more than one) }\end{array}$ & $\begin{array}{ll}\text { - } & \text { General } \\
\text { - } & \text { Local/sedation } \\
\text { - } & \text { Local } \\
\text { - } & \text { N/A } \\
\end{array}$ \\
\hline $\begin{array}{l}\text { Prophylactic antibiotic (Abx) } \\
\text { used (you can choose more } \\
\text { than one) }\end{array}$ & $\begin{array}{ll}\text { - } & \text { PNE } \\
\text { - } & \text { Stag I } \\
\text { - } & \text { Stage II } \\
\text { - } & \begin{array}{l}\text { Entire device implant after } \\
\text { successful of PNE }\end{array}\end{array}$ \\
\hline $\begin{array}{l}\text { Type of Abx preoperative (you } \\
\text { can choose more than one) }\end{array}$ & $\begin{array}{ll}\text { - } & \text { Cephalosporins } \\
\text { - } & \text { Aminoglyside } \\
\text { - } & \text { Quinolones } \\
\text { - } & \text { Other (please specify) }\end{array}$ \\
\hline
\end{tabular}




\begin{tabular}{|c|c|}
\hline Duration of Abx & $\begin{array}{l}\text { - One dose preoperative } \\
\text { - Multiple doses for } 1 \text { week } \\
\text { preoperative } \\
\text { - Other (please specify) }\end{array}$ \\
\hline $\begin{array}{l}\text { Surgical site preparation } \\
\text { (you can choose more than } \\
\text { one) }\end{array}$ & $\begin{array}{l}\text { - Ask the patient to take shower at } \\
\text { the day of surgery } \\
\text { - Washing using diluted povidone } \\
\text { - } \begin{array}{l}\text { Preparation using povidone } \\
\text { based solution }\end{array} \\
\text { - Preparation using chlorhexidine } \\
\text { based solution } \\
\text { - Other (please specify) }\end{array}$ \\
\hline $\begin{array}{l}\text { For localization of } S 3 \text { foramen, } \\
\text { due you use: (you can choose } \\
\text { more than one) }\end{array}$ & $\begin{array}{ll}\text { - } & \text { AP view } \\
\text { - } & \text { Lateral view } \\
\text { - } & \text { Both } \\
\text { - } & \text { Other (please specify) }\end{array}$ \\
\hline $\begin{array}{l}\text { Position of electrode in the } \\
\text { foramen: }\end{array}$ & $\begin{array}{ll}\text { - } & \text { Upper-medial } \\
\text { - } & \text { Upper-lateral } \\
\text { - } & \text { Lower-medial } \\
\text { - } & \text { Lower-lateral } \\
\text { - } & \text { Doesn't matter }\end{array}$ \\
\hline stylet used: & $\begin{array}{ll}\text { - } & \text { Curved stylet } \\
\text { - } & \text { Straight stylet }\end{array}$ \\
\hline $\begin{array}{l}\text { Minimal number of electrode } \\
\text { stimulation requirement for } \\
\text { good position: }\end{array}$ & 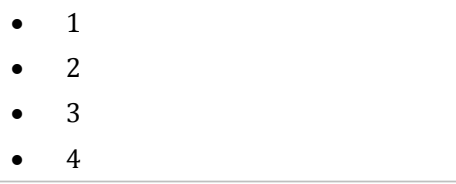 \\
\hline Postoperative Antibiotics & $\begin{array}{ll}\text { - } & \text { No } \\
\text { - } & \text { Yes (No. of days) }\end{array}$ \\
\hline Time of programming & $\begin{array}{ll}\text { - } & \text { Immediate post-op } \\
\text { - } & \text { Within } 1-2 \text { weeks } \\
\text { - } & \text { After } 4 \text { weeks }\end{array}$ \\
\hline $\begin{array}{l}\text { How many program to be done } \\
\text { at a beginning }\end{array}$ & $\begin{array}{ll}- & 1 \\
\text { - } & 2 \\
\text { - } & 3 \\
\text { - } & 4\end{array}$ \\
\hline $\begin{array}{l}\text { Do you do a routine } \\
\text { postoperative sacral } x \text {-ray } \\
\text { to document the electrode } \\
\text { position }\end{array}$ & $\begin{array}{l}\text { - } \quad \text { Yes } \\
\text { - } \quad \text { No }\end{array}$ \\
\hline $\begin{array}{l}\text { What are the factors you are } \\
\text { looking for during routine } \\
\text { follow up (you can choose } \\
\text { more than one) }\end{array}$ & $\begin{array}{ll}\text { - } & \text { Symptom } \\
\text { - } & \text { Wound } \\
\text { - } & \text { Battery life } \\
\text { - } & \text { Impedance }\end{array}$ \\
\hline
\end{tabular}

\begin{tabular}{|c|c|}
\hline $\begin{array}{l}\text { Do you have any special } \\
\text { indication to use monopolar } \\
\text { or bipolar program, indicate } \\
\text { please }\end{array}$ & $\begin{array}{ll}\text { - } & \text { No } \\
\text { - } & \text { Yes (specify) }\end{array}$ \\
\hline $\begin{array}{l}\text { In case of pain at the site of } \\
\text { battery, due you do (you can } \\
\text { choose more than one) }\end{array}$ & $\begin{array}{ll}\text { - } & \text { Daily oral pain medication } \\
\text { - } & \text { Long acting local analgesia } \\
\text { - } & \text { Relocation of the battery } \\
\text { - } & \text { Referral to pain clinic } \\
\text { - } & \text { Remove the device } \\
\text { - } & \text { Other (please specify) }\end{array}$ \\
\hline $\begin{array}{l}\text { What do you do for salvage } \\
\text { treatment (you can choose } \\
\text { more than one) }\end{array}$ & 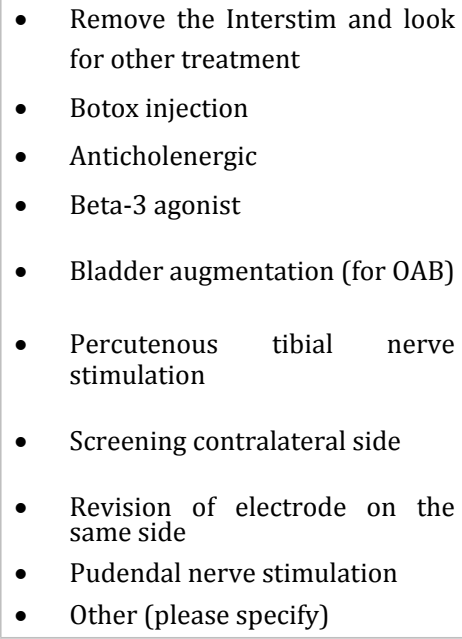 \\
\hline Other Comments & \\
\hline
\end{tabular}

\section{Results}

Forty-nine implanters from 19 countries filled out the survey. As in some countries/area where only limited numbers of surgeons are qualified to perform this type of implantation, the demographic summary was not reported in this presentation.

Approximately 69.39\% (34/49) of implanters had experience with InterStim ${ }^{\circledR}$ for more than 5 years. The number of annual implant varied between the responders, with $35.42 \%(17 / 48)$ of implanters who had implanted less than 10 devices per year Because SNM is a costly procedure, the government and insurance companies usually cover the cost of the surgical implant.

\section{Indications:}

The indications for the implants were urgency frequency syndrome [Overactive Bladder (OAB) and neurogenic bladder], chronic urinary retention, chronic pelvic pain, and fecal incontinence (Figure 1).

\section{Preoperative Evaluation:}

The preoperative evaluation of patients varied between implanters, although medical history and physical examination were common for every patient according to the responders. 
There was several investigation tools used to evaluate the patients before SNM implants. It was found that $42.86 \%$ of implanters used the voiding diary published by Medtronic Inc., and $57.14 \%$ used other diaries (either validated or their own diary) (Figure 2). Routine preoperative sacral X-ray, simple uroflowmetry, multichannel urodynamic study and Cystoscopy done by implanter are $67.35 \%, 72.92 \%, 79,17 \%$ and $40,43 \%$ respectively. The factors implicated in the choice the battery size were surgeon preference (51.22\%), body characteristic (39.02\%), patient preference $(21.92 \%)$, cost $(14.63 \%)$, indication $(12.2 \%)$ and age $(9.76 \%)$.

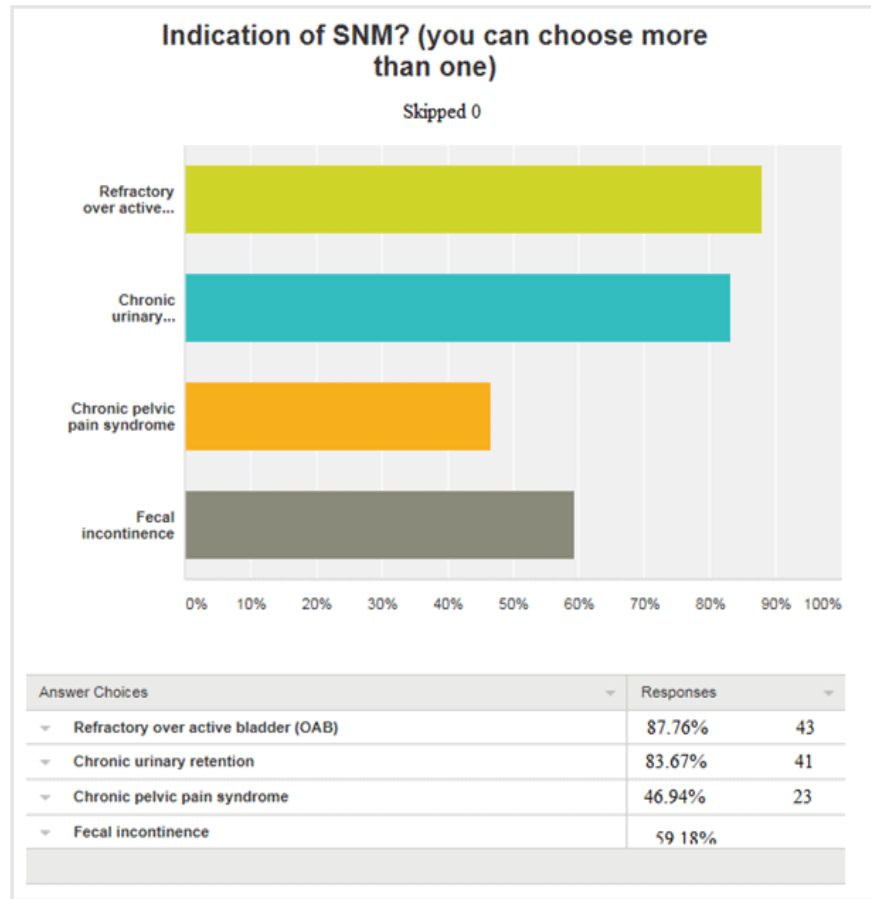

Figure 1

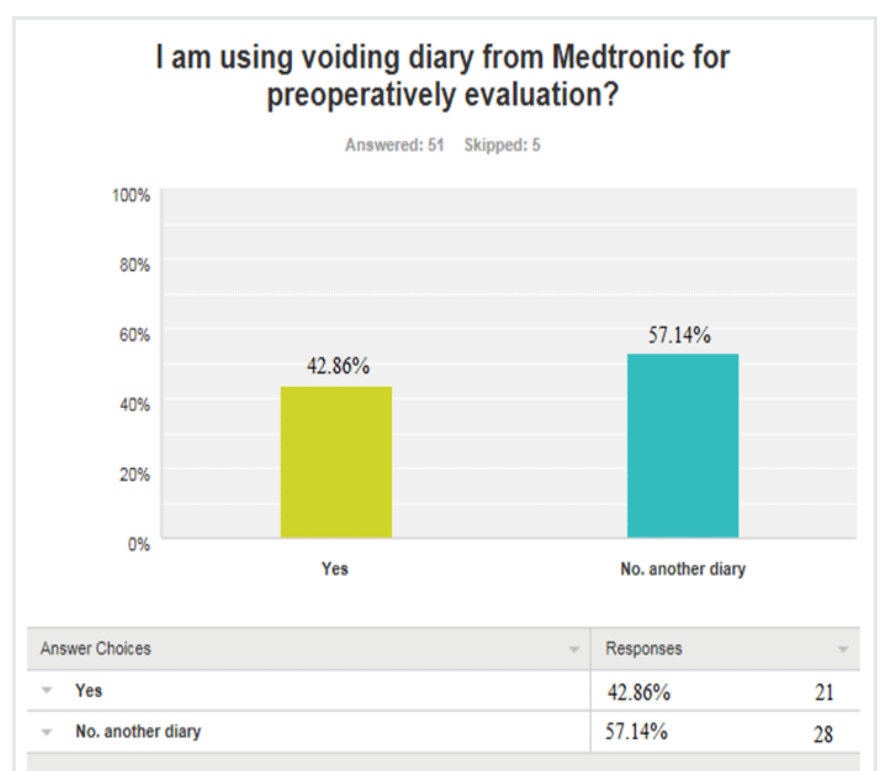

Figure 2

\section{Screening Test:}

Staged implant was the most common method used for screening (46.94\%), whereas only $28.57 \%$ of the responders offered Percutaneous Nerve Evaluation (PNE). The rest of the implanters used both approaches, depending mostly on the indication and body habitus.

Regarding the side chosen for the screening test, it was found that $71.74 \%$ of the responders were performing unilateral sacral nerve stimulation for screening. The location of the wire electrode was guided under fluoroscopy for PNE in $75 \%$ of the responders; moreover, fluoroscopy was used for indication of good electrode position by $48.84 \%$ implanters. The indication of an appropriate electrode position depended on sensory and motor response for $67.44 \%$ and $79.07 \%$ of the implanters, respectively.

Local anesthesia with or without sedation was used for electrode implant by most implanters (85.1\%), and $34.88 \%$ of implanters performed a routine sacral X-ray after PNE.

\section{Prophylactic Antibiotic:}

The preparation of the surgical site varied among the implanters. Most of the implanters used antibiotic prophylaxis at the time of stage I, and at the time of the battery implant. For the PNE test, only $26.09 \%$ used prophylactic antibiotics. Cephalosporins were the most commonly used $(84.78 \%$ of responders), although other antibiotics were used as well (like aminoglyside, quinolones and penicillin). Most of implanters gave one dose of prophylactic antibiotic (73.91\%), followed by antibiotic for 1-7 days.

\section{Surgical Technique:}

Most of the implanters (68.09\%) used both anteroposterior and lateral views of the sacrum with fluoroscopy throughout the electrode implant. About half of the responders aimed the electrode into the upper medial location of the 3rd sacral foramen. A curved stylet was used to facilitate the introduction of the electrode into the foramen by $63.83 \%$ of the implanters. About two-thirds of implanters considered a minimum of 2-3 electrodes stimulations/bellows contractions as the optimal position for the electrode.

Most of implanters activated the device immediately after implant, and $47.73 \%$ assigned the patient with one program at the start.

\section{Postoperative Care:}

During the follow-up visits, the parameters evaluated included symptoms, appearance of the wound, the battery life, and impedance of the InterStim ${ }^{\circledR}$ device.

A little over half of the responders (56.52\%) performed a routine sacral X-ray during the follow-up.

About a quarter of the responders (26.09\%) preferred bipolar mode of stimulation, especially in the case of pain at the battery site.

\section{Complications:}


Pain at the site of the battery implant is an uncommon complication. It can be managed by oral analgesia, injection of local anesthetic around the device, relocation of the device to a deeper pocket, reprogramming, turning the device off, referral to a pain clinic, and, if the pain was intolerable, the device can be removed.

In case of failure of the SNM to produce the desired clinical benefit, almost half of the implanters $(46.67 \%)$ had to remove the device. In order to manage the patient's symptoms, other options depended on the indication, and included intravesical Botox injection, anticholinergics, beta agonists, bladder augmentation, percutaneous tibial nerve stimulation, revision of electrode or screening the contralateral side, and pudendal nerve stimulation.

\section{Discussion}

The procedure for SNM varies according to the hospital site, the surgeon's personal preference, and the way the surgeon has been proctored for the surgical and follow-up techniques.

Preoperative evaluation was variable between the implanters. Clinical assessment, including history and physical examination, should be done for every patient. Other tests used by the implanters before SNM implant included cystoscopy, uroflowmetry, an urodynamic study, and sacral X-ray, with no evidence supporting their approach.

Infection of the device is an uncommon (6.1\%) complication [14]. To decrease the risk of infection, implanters who used different types of prophylactic antibiotics most commonly used cephalosporine (84.78\%), either one dose or multiple doses, for 1-14 days. Most of the implanters gave one dose of prophylactic antibiotic (73.91\%). Also, the surgical site preparation differed between implanters. While some implanters asked the patients to take a shower before surgery, others performed washing with diluted povidone, or a preparation using a povidone or a chlorhexidine-based solution.

Unilateral stage implant is the most commonly used approach for screening. PNE was described as a blind procedure, but $75 \%$ of the implanters in this survey were performing it under fluoroscopic guidance.

Implantation of the electrode varied between the implanters. Sensory, levator ani and foot/big toe movement were used to indicate an appropriate electrode position. Number of electrodes per stimulation at stage implant did not make a difference in the outcome, despite a higher voltage needed for a $<4$ electrode stimulation [15]. Most of the implanters in this survey consider a 2-4 electrode position as being required for a good position. Most of the implanters tried to implant the electrode in the upper medial aspect of S3 foramen. Although usage of a curved stylet may increase the battery life, it is only being utilized by $36.17 \%$ of the responders [16].

Most of the implanters initiated the activation the device immediately after the implant, and half of the implanters did a routine sacral X-ray, although it is usually unhelpful. In a postoperative follow-up, implanters have to evaluate the patients' symptoms, wound healing, and do programming if needed [17].

If the patient experiences pain at the battery site, choosing bipolar is an appropriate initial step. The options to manage battery site pain include program manipulation to bipolar, daily oral analgesic, local analgesia injection, battery relocation, referral to pain clinic, and removal of the device [18].

Salvage treatment can be done with or without SNM, including oral medication (anticholenergic, beta 3 agonist), intravesical Botox injection, percutaneous tibial nerve stimulation, unilateral or contralateral revision of electrode, and pudendal nerve stimulation or bladder augmentation [19].

The strength of this survey that it was distributed to SNM implanters worldwide through ICS and covers all major aspects of SMN implantation. We are aware of some limitation in this study, small number of responders, few responders skipped some questions, and the demographic summary was not reported in this presentation.

\section{Conclusion}

In the current manuscript, we described the different nuances in the standard of practice for surgeons involved in the delivery of SNM therapy.

As evidenced by the discrepancy in the responses, we think that this is the initial step in the preparation for a guideline describing the best policy to deliver the SNM.

\section{References}

1. Thompson JH, Sutherland SE, SiegelSW.Siegel. Sacral neuromodulation: Indian J Urol. 2010;26(3):379-384. doi: 10.4103/0970-1591.70576

2. Health Quality Ontario. Sacral nerve stimulation for urinary urge incontinence, urgency-frequency, urinary retention, and fecal incontinence: an evidence-based analysis. Ont Health Technol Assess Ser. 2005;5(3):1-64.

3. Siegel S, Noblett K, Mangel J, Griebling TL, Sutherland SE, Bird ET, et al. Results of a prospective, randomized, multicenter study evaluating sacral neuromodulation with InterStim therapy compared to standard medical therapy at 6-months in subjects with mild symptoms of overactive bladder. Neurourol Urodyn. 2015;34(3):224-230. doi: $10.1002 /$ nau.22544

4. Medtronic-sponsored research. InterStim Therapy Clinical Summary 2014.

5. Siegel SW, Moeller SE. Sacral Neuromodulation for the Treatment of Overactive Bladder (OAB) In: Raz S, Rodriquez L, editors. Female Urology. 3rd ed. Philadelphia: WB Saunders Company; 2008. pp. 26676. Ch. 22.

6. Sutherland SE, Siegel SW. Sacral nerve stimulation for overactive bladder symptoms. In: Kreder K, Dmochowski R, editors. The Overactive Bladder Evaluation and Management. London: Informa HealthCare; 2007. pp. 303-18. Ch 26.

7. Schmidt RA, Jonas U, Oleson KA, Janknegt RA, Hassouna MM, Siegel SW, et al. Sacral nerve stimulation for treatment of refractory urinary urge incontinence. Sacral Nerve Stimulation Study Group J Urol. 1999;162(2):352-357.

8. Hassouna MM, Siegel SW, Nÿeholt AA, Elhilali MM, van Kerrebroeck $\mathrm{PE}$, Das AK, et al. Sacral neuromodulation in the treatment of urgency- 
frequency symptoms: a multicenter study on efficacy and safety. J Urol. 2000;163(6):1849-1854

9. Jonas U, Fowler CJ, Chancellor MB, Elhilali MM, Fall M, Gajewski JB, et al. Efficacy of sacral nerve stimulation for urinary retention: results 18 months after implantation. J Urol. 2001;165(1):15-19.

10. Pettit PD, Thompson JR, Chen AH. Sacral neuromodulation: new applications in the treatment of female pelvic floor dysfunction. Curr Opin Obstet Gynecol. 2002;14(5):521-255.

11.Seif C, Eckermann J, Bross S, et al. Findings with bilateral sacral neuromodulation. Neuromodulation. 2004;7:141-145.

12. Maher CF, Carey MP, Dwyer PL, Schluter PL. Percutaneous sacral nerve root neuromodulation for intractable interstitial cystitis. J Urol. 2001;165(3):884-846.

13. Whitmore KE, Payne CK, Diokno AC, Lukban JC. Sacral neuromodulation in patients with interstitial cystitis: a multicenter clinical trial. Int Urogynecol J Pelvic Floor Dysfunct. 2003;14(5):305-308. doi: 10.1007/s00192-003-1080-1

14. Siegel SW, Catanzaro F, Dijkema HE, Elhilali MM, Fowler CJ, Gajewski $\mathrm{JB}$, et al. Long-term results of a multicenter study on sacral nerve stimulation for treatment of urinary urge incontinence, urgencyfrequency, and retention. Urology. 2000;56(6 Suppl 1):87-91.

15. Gilleran JP, Killinger K, Boura J, Peters KM. Number of active electrodes at time of staged tined lead interstim implant does not impact clinical outcomes. Neurourol Urodyn. 2016;35(5):625-629. doi: 10.1002/ nau. 22766

16. Jacobs SA, Lane FL, Osann KE, Noblett KL. Randomized prospective crossover study of interstim lead wire placement with curved versus straight stylet. Neurourol Urodyn. 2014;33(5):488-492. doi: 10.1002/ nau. 22437

17. Gaynor-Krupnick DM, Dwyer NT, Rittenmeyer H, Kreder KJ. Evaluation and management of malfunctioning sacral neuromodulator. Urology. 2006;67(2):246-249. doi: 10.1016/j.urology.2005.08.055

18. Brazzelli M, Murray A, Fraser C. Efficacy and safety of sacral nerve stimulation for urinary urge incontinence: a systematic review. J Urol. 2006;175(3 Pt 1):835-841. doi:10.1016/S0022-5347(05)00326-5

19. Truzzi JC, Gomes CM, Bezerra CA, Plata IM, Campos J, Garrido GL, et al. Int Braz J Urol. 2016;42(2):199-214. doi: 10.1590/S1677-5538. IBJU.2015.0367 